\section{Complex Leopard non-associated congenital night blindness in Mangalarga Marchador foals}

\author{
Cegueira noturna congênita em potros da raça Mangalarga \\ Marchador não associada ao Complexo do Leopardo
}

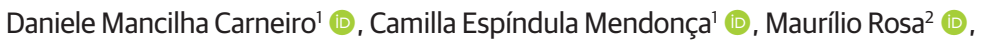 \\ Denise Monnerat Nogueira 3 (D) \& Leonardo Rodrigues de Lima ${ }^{4}$ (D) \\ 'Student of veterinary medicine. Universidade Federal Rural do Rio de Janeiro - UFRRJ, Seropédica, RJ, Brasil \\ 2Postgraduate student. Programa de Pós Graduação em Medicina Veterinária, Universidade Federal Rural do Rio de Janeiro - \\ UFRRJ, Seropédica, RJ, Brasil \\ ${ }^{3}$ Doctor. Departamento de Genética, Instituto de Biologia e Ciências da Saúde, Universidade Federal Rural do Rio de Janeiro - \\ UFRRJ, Seropédica, RJ, Brasil \\ ${ }^{4}$ Doctor. Departamento de Medicina e Cirurgia Veterinária, Instituto de Veterinária, Universidade Federal Rural do Rio de \\ Janeiro - UFRRJ, Seropédica, RJ, Brasil
}

\begin{abstract}
The report describes two cases of four- and five-month-old Mangalarga Marchador fillies showing signs of night blindness. The animals appeared to have disorientation at night. Ophthalmic examination revealed all parameters as normal except for the absence of menace response in the penumbra. Fundoscopy examination did not demonstrate any morphological abnormalities in the retina. Electroretinography examination confirmed a failure in the electrical activity of rods, which are retinal photoreceptors responsible for night vision. However, we noted a small reduction in the electrical activity of the cones, suggesting that the animals may have visual difficulties in clear environments. Genomic analysis of the hair follicles from their mane (Veterinary Genetics Laboratory/UC - Davis, USA) did not reveal the presence of homozygosity for the Leopard Complex, a gene pool associated with congenital stationary nocturnal blindness (CSNB) in horses with depigmented hair. Outcomes of the studbook analysis suggested the presence of a kinship among the described animals. Additional research is required for the genomic determination of nocturnal blindness in Mangalarga Marchador horses.
\end{abstract}

Keywords: horse, genetics, Brazilian race, vision, electroretinography.

\section{Resumo}

Objetivou-se relatar dois casos clínicos de potras com 4 e 5 meses de idade da raça Mangalarga Marchador demonstrando sinais de cegueira noturna. Os animais apresentavam histórico de desorientação no período noturno. No exame oftálmico, todos os parâmetros foram normais, exceto pela ausência de reflexo de ameaça na penumbra. A fundoscopia não demonstrou nenhuma anormalidade morfológica da retina. A eletrorretinografia confirmou falha na atividade elétrica dos bastonetes, fotorreceptores da retina responsáveis pela visão noturna. No entanto, percebeu-se também uma pequena redução da atividade elétrica dos cones, demonstrando que os animais podem ter uma dificuldade visual em ambientes claros. O exame genômico dos folículos pilosos (Veterinary Genetics Laboratory/UC - Davis, USA) não demonstrou homozigose para Complexo do Leopardo, conjunto de genes associado à cegueira noturna estacionária congênita (CSNB) em cavalos com pelagem despigmentada. A análise genealógica demonstrou um parentesco em comum entre os animais descritos. Assim, tornam-se necessárias pesquisas adicionais para determinação genômica da cegueira noturna em equinos da raça Mangalarga Marchador.

Palavras-chave: cavalo, genética, raça brasileira, visão, eletrorretinografia.

\section{Introduction}

Vision is an essential sense to allow free-living animals to interact with the environment in order to promptly identify threats from predators and terrain obstacles. In sport horses, good vision is necessary for performance efficiency and rider safety. Therefore, problems associated with vision have important connotations about animal welfare and sporting safety, leading to important financial losses.

Genetic and hereditary eye disorders are well characterized in humans (Schubert \& Bornschein, 1952; Yanoff et al., 2016) and canine species (Pickett et al., 1991; Maggs et al., 2012). However, only a
How to cite: Carneiro, D. M., Mendonça, C. E., Rosa, M., Nogueira, D. M., \& Lima, L. R. (2020). Complex Leopard non-associated congenital night blindness in Mangalarga Marchador foals. Brazilian Journal of Veterinary Medicine, 42 . e106220. doi: 10.29374/2527-2179.bjvm106220

Financial support: None.

Conflict of interests: No conflict of interests declared concerning the publication of this article.

Received: September 28, 2019

Accepted: October 25, 2019.

The study was carried out at Universidade Federal Rural do Rio de Janeiro - UFRRJ Seropédica, RJ, Brasil and at Veterinary Genetics Laboratory, Davis, UC, EUA.

\section{*Correspondence}

Leonardo Rodrigues de Lima

Departamento de Medicina e Ciências Veterinárias, Universidade Federal Rural do

Rio de Janeiro - UFRRJ

Campus Seropédica, Rodovia BR 465,

Km 07, s/n Zona Rural,

CEP 23851-790 - Seropedica (RJ), Brasil

E-mail: leoveterinariojf@gmail.com 
few studies have reported about congenital visual dysfunctions in horses, which may be potentially hereditary or associated with different races, coats, and families of equine species. The genotype associated with certain cutaneous pigmentation patterns in several equine species has been positively correlated with normal and abnormal eye phenotypic characteristics (Bellone, 2017). Iris heterochromia associated with compound coats in Pampa horses has been reported (Crispin, 2000). Ophthalmic diseases associated with skin pigmentation in horses include multiple congenital eye abnormalities (MCOA) and congenital stationary night blindness (CSNB) (Ewart et al., 2000; Bellone et al., 2013). Regarding MCOA, ophthalmic abnormalities associated with homozygosis occur for the gray coat, such as multiple cysts in the iris, cornea globosa, iris hypoplasia, dyscoria, and retinal and pectinate ligament dysplasia (Ramsey et al., 1999a; Ewart et al., 2000). In CSNB, homozygosis for the Leopard Complex (LP) genes determine a characteristic coat pattern in the Appaloosa breed and the absence of an ion channel (TRPM1) in the bipolar cells associated with retinal rods (Bellone et al., 2013). The latter are the photoreceptor cells or neurons that capture low-intensity light sources in dark environments or at night. Therefore, homozygotes for the LP genes lack functionality of the TRPM1 channels, resulting in the absence of scotopic vision, consequently characterizing night blindness (Bellone et al., 2013).

Therefore, little is known about potential eye disorders associated with the coats of Mangalarga Marchador horses. We aimed to report two clinical cases of congenital night blindness in two fillies of the Mangalarga Marchador breed with a depigmented coat and a common close ancestor.

\section{History}

Two fillies of the Mangalarga Marchador breed were admitted to the Veterinary Hospital, one at 5 months of age (case 1 ) and the other at 4 months of age (case 2 ), both with gray coats. The owners reported that the horses showed low visual acuity and disorientation at night. Genealogical research suggested that the parent (father) of the equine of case 1 was the maternal grandfather of the equine of case 2, although the animals had different owners. Physical examination in a scotopic environment showed no menace response in both animals. In an illuminated environment, the menace response was normal. Fundoscopic examination (Figure 1) suggested no abnormalities. Furthermore, electroretinography and genomic research were performed to verify the presence of homozygosis for the Leopard Complex genes.

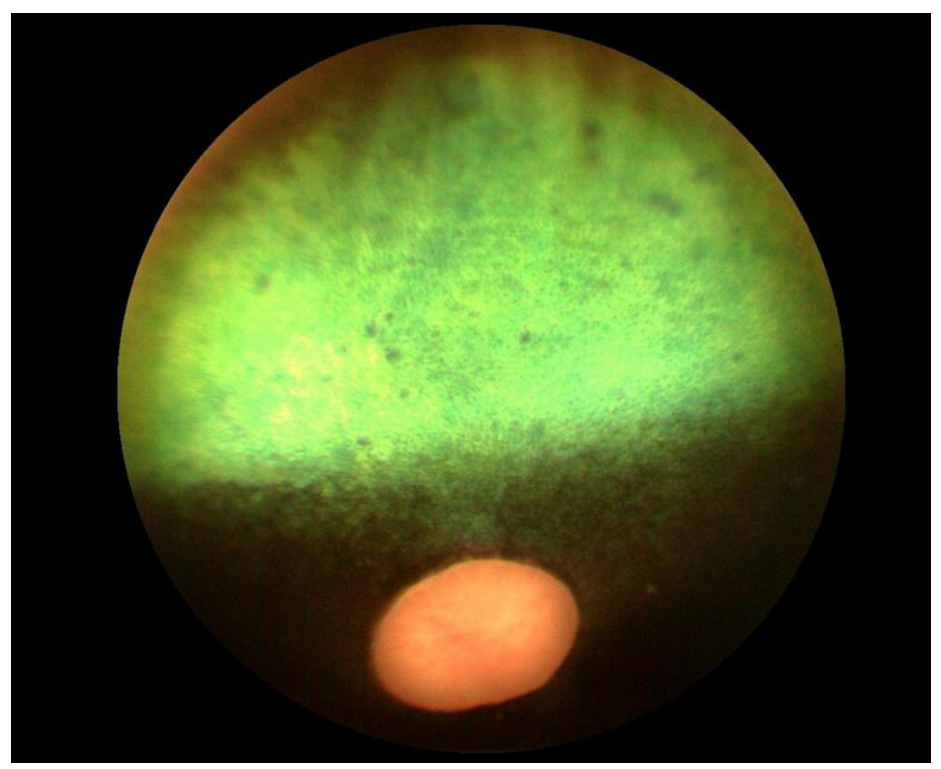

Figure 1. Digital fundscopy showing no morphological changes in the retina. 


\section{Electroretinography}

The animals were subjected to several examinations according to the specific electroretinographic protocol. The examinations were conducted in the same environment, according to the ISCEV (International Society for Clinical Electrophysiology of Vision) standards, under the same light conditions and adaptation time to darkness (20 minutes) (Ekesten et al., 2013). The fillies were intravenously sedated with $1 \%$ detomidin (detomidin, Syntec Laboratory) at $20 \mu \mathrm{g} / \mathrm{kg}$, and locoregional blocking of the auriculopalpebral nerve on both sides with $2.5 \mathrm{~mL}$ of lidocaine without a vasoconstrictor (Xylestesin, Cristalia). For mydriasis of the pupils, tropicamide was instilled at $10 \mathrm{mg} / \mathrm{mL}$ (Midriacyl, Alcon/Novartis bioscience). The corneas were anesthetized by topically administering proxymetacaine hydrochloride (Anestalcon, Alcon Laboratórios do Brazil) at 0.5\%. Following this administration, we used the $2 \%$ methylcellulose eye lubricant (Ophthalmos Rohto) to fix the erg-Jet electrode to the corneal surfaces.

We performed an electroretinographic examination in a scotopic environment with the HMsERG model 1000 (Handheld Multi-species ElectroRetinoGraph) equipment, along with white LED lamps and a dome to ensure uniform illumination. The ground electrode, a stainless steel subdermal needle electrode (Occuscience LLC), was installed in the subcutaneous tissue at the base of the occipital bone. The reference electrode, a stainless steel subdermal needle electrode (Occuscience LLC), was placed in the subcutaneous tissue positioned $3 \mathrm{~cm}$ from the lateral corner of the eye. The active electrode ERG Jet Contac lens (Fabrinal AS) was placed on the corneal surface. We used the normal response values in full-field electroretinograms in horses using the same protocol, described in Table 1 (Rosa et al., 2014), as that of the reference.

Four initial, low-intensity light flashes $\left(10 \mathrm{mcd} . \mathrm{s} / \mathrm{m}^{2}\right)$ were used for assessing rod response, a second brighter flash (3000 mcd.s $/ \mathrm{m}^{2}$ ) for the combined rod and cone response, and a third bright flash (10000 mcd.s $\left./ \mathrm{m}^{2}\right)$ for cone response. In addition, a high-intensity $\left(10000 \mathrm{mcd} . \mathrm{s} / \mathrm{m}^{2}\right)$ flicker light test (Flicker) was performed, with 128 flashes every $0.033 \mathrm{sec}$, for cone response.

The full-field ERG results, tables, and curves were evaluated and generated from ERGView 4.380R software. We analyzed only the values related to wave " $\mathrm{b}$ " in the case of the specific test for rods and the specific Flicker test for cones. However, the combined response for cones and rods was evaluated by analyzing the respective values of waves "a" and "b" in both animals for the other results Table 1.

Table 1. Average amplitudes of waves "a" and "b" in the photopic and scotopic stimulus phases, in the left (LE) and right (RE) eye of normal horses submitted to total field electroretinography (Adapted of Rosa et al., 2014).

\begin{tabular}{|c|c|c|c|c|}
\hline & Photoreceptors & Phase & Average RE & Average LE \\
\hline Wave "a" $(\mu \mathrm{V})$ & Cone & Photopic & 106.39 & 115.96 \\
\hline Implicit time (ms) & & & 16.28 & 11.09 \\
\hline Wave "b" ( $\mu \mathrm{V})$ & Cone & Photopic & 300.83 & 314.23 \\
\hline Implicit time (ms) & & & 60.87 & 56.6 \\
\hline Wave "a" $(\mu \mathrm{V})$ & Rod & Scotopic & 25.95 & 36.1 \\
\hline Implicit time (ms) & & & 10.93 & 8.47 \\
\hline Wave "b" $(\mu \mathrm{V})$ & Rod & Scotopic & 224.1 & 226.56 \\
\hline Implicit time (ms) & & & 80.29 & 67.95 \\
\hline
\end{tabular}


The left eye (OS) and right eye (OD) responses of the animal in case 1 are summarized in Table 2. In the OS, the mean amplitude of wave " $\mathrm{b}$ " for rods was $9.2 \mu \mathrm{V}$ with an implicit time (IT) of $16.7 \mathrm{~ms}$. The combined response of rods and cones for wave "a" was $44.9 \mu \mathrm{V}$ with an IT of $0.3 \mathrm{~ms}$ and for wave "b" was $63.7 \mu \mathrm{V}$ with an IT of $62.1 \mathrm{~ms}$. The average response of wave "a" for cones was $24.7 \mu \mathrm{V}$ with an IT of $0.0 \mathrm{~ms}$ and wave "b" with $61.1 \mu \mathrm{V}$ at $4.8 \mathrm{~ms}$. Flicker's mean response was $45.5 \mu \mathrm{V}$ and the IT was $5.3 \mathrm{~ms}$ for wave "b". In OD, the mean amplitude of "b" wave for rods was $9.5 \mu \mathrm{V}$ with IT of $64.8 \mathrm{~ms}$. The combined response of rods and cones was $11.2 \mu \mathrm{V}$ and an IT of $0.2 \mathrm{~ms}$ for wave "a" and $27.6 \mu \mathrm{V}$ with an IT of $1.0 \mathrm{~ms}$ for wave "b" The mean response for cones was $18.9 \mu \mathrm{V}$ with $0.3 \mathrm{~ms}$ for wave "a" and $33.1 \mu \mathrm{V}$ at $5.4 \mathrm{~ms}$ for wave "b". The average response of Flicker was for wave "b" with $22.8 \mu \mathrm{V}$ at $4.4 \mathrm{~ms}$.

The responses for the left eye (OS) and the right eye (OD) of the animal in case 2 are summarized in Table 3. In OS, the mean amplitude of wave "b" for rods was $1.8 \mu \mathrm{V}$ with an IT of $7.4 \mathrm{~ms}$. The combined response of rods and cones for wave "a" was $2.6 \mu \mathrm{V}$ with an IT of $10.3 \mathrm{~ms}$ and for wave "b" was $12.5 \mu \mathrm{V}$ with an IT of $75.3 \mathrm{~ms}$. The mean response of cones for wave "a" was $0.1 \mu \mathrm{V}$ with an IT of $13.1 \mathrm{~ms}$ and that of $21.4 \mu \mathrm{V}$ and an IT of $50.3 \mathrm{~ms}$ for wave "b". Mean response to flicker was wave "b" with $11.2 \mu \mathrm{V}$ and an IT of $31.2 \mathrm{~ms}$. In OD, the mean amplitude of wave " $b$ " for rods was $11.3 \mu \mathrm{V}$ with an IT of $147.3 \mathrm{~ms}$. The combined response of rods and cones for wave "b" was $32.5 \mu \mathrm{V}$ with an IT of $149.0 \mathrm{~ms}$. The mean response of cones for wave "a" was $17.3 \mu \mathrm{V}$ with an IT $0.0 \mathrm{~ms}$ and that for wave "b" was $52.5 \mu \mathrm{V}$ with an IT $132.6 \mathrm{~ms}$. The mean response of flicker light for wave "b" was $10.0 \mu \mathrm{V}$ with an IT of $0.1 \mathrm{~ms}$.

Table 2. Electroretinographic response of a 5-month-old female horse (case 1) of the breed Mangalarga Marchador presenting with congenital night blindness.

\begin{tabular}{lcccccc} 
Response & Eye & $\begin{array}{c}\text { Flash } \\
\text { intensity } \\
\left(\mathbf{m} \mathbf{c} . \mathbf{s} / \mathbf{m}^{2}\right)\end{array}$ & $\begin{array}{c}\text { a-wave } \\
\text { amplitude } \\
(\mathbf{u V})\end{array}$ & $\begin{array}{c}\text { a-wave } \\
\text { implict } \\
\text { time (mS) }\end{array}$ & $\begin{array}{c}\text { b-wave } \\
\text { amplitude } \\
\text { (uV) }\end{array}$ & $\begin{array}{c}\text { b-wave } \\
\text { implict } \\
\text { time (mS) }\end{array}$ \\
\hline Rods & Left & 10 & 1.0 & 6.0 & 9.2 & 16.7 \\
Rods/Cones & Left & 3000 & 44.9 & 0.3 & 63.7 & 62.1 \\
Cones & Left & 10000 & 24.7 & 0.0 & 61.1 & 4.8 \\
Flicker & Left & 10000 & - & - & 45.5 & 5.3 \\
Rods & Right & 10 & 2.9 & 22.3 & 9.5 & 64.8 \\
Rods/Cones & Right & 3000 & 11.2 & 0.2 & 27.6 & 1.0 \\
Cones & Right & 10000 & 18.9 & 0.3 & 33.1 & 5.4 \\
Flicker & Right & 10000 & - & - & 22.8 & 4.4 \\
\hline
\end{tabular}

Table 3. Electroretinographic response of a 4-month-old female horse (case 2) of the breed Mangalarga Marchador presenting with congenital night blindness.

\begin{tabular}{lcccccc}
\hline Response & Eye & $\begin{array}{c}\text { Flash } \\
\text { intensity } \\
\left(\mathbf{m} \mathbf{c} . \mathbf{s} / \mathbf{m}^{2}\right)\end{array}$ & $\begin{array}{c}\text { a-wave } \\
\text { amplitude } \\
(\mu \mathrm{V})\end{array}$ & $\begin{array}{c}\text { a-wave } \\
\text { implict time } \\
(\mathbf{m S})\end{array}$ & $\begin{array}{c}\text { b-wave } \\
\text { amplitude } \\
(\mu \mathrm{V})\end{array}$ & $\begin{array}{c}\text { b-wave } \\
\text { implict time } \\
(\mathrm{mS})\end{array}$ \\
\hline Rods & Left & 10 & 8.2 & 46.1 & 1.8 & 7.4 \\
Rods/Cones & Left & 3000 & 2.6 & 10.3 & 12.5 & 75.3 \\
Cones & Left & 10000 & 0.1 & 13.1 & 21.4 & 50.3 \\
Flicker & Left & 10000 & - & - & 11.2 & 31.2 \\
Rods & Right & 10 & 1.6 & 37.4 & 11.3 & 147.3 \\
Rods/Cones & Right & 3000 & 2.7 & 11.4 & 32.5 & 149.0 \\
Cones & Right & 10000 & 17.3 & 0.0 & 52.5 & 132.6 \\
Flicker & Right & 10000 & - & - & 10.0 & 0.1 \\
\hline
\end{tabular}


Thus, we obtained the ERG curves of both animals, as presented in Figure 2.
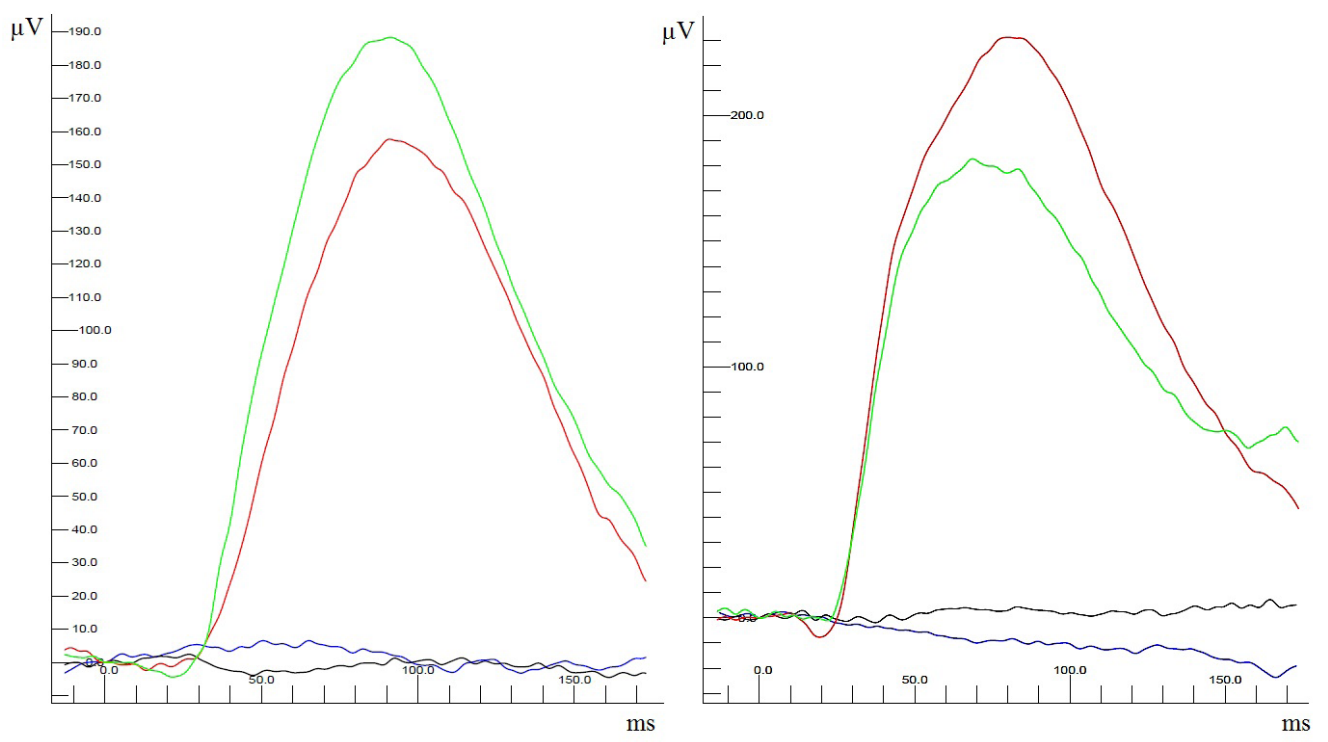

\section{a}

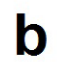

Figure 2. Curve of the horses ERG, translating the electrical activity of rod photoreceptors ( $\mu \mathrm{V}$ ) and implicit time (ms). Case 1 represented by graph (a) and case 2 by graph (b). The blue and black lines represent, respectively, activities in the right and left eyes of animals with night blindness. The green and red lines represent, respectively, activities in the right and left eyes of normal animals.

\section{Genetic examination}

Hair follicles from the horses' mane were collected, packed in a paper envelope, and sent to the Veterinary Genetics Laboratory (UC Davis, USA) to verify the presence of homozygosis for the Leopard Complex genes. As genomic examination did not reveal homozygosis, we excluded the possibility that both cases of night blindness were related to the Leopard Complex.

\section{Discussion}

Currently, there are no published reports on the presence of congenital night blindness in Mangalarga Marchador horses. Initially, a congenital form of nocturnal blindness reported in horses with a depigmented coat was considered due to specific phenotypic characteristics found in the study animals. Congenital stationary night blindness (CSNB), associated with the Leopard Complex (LP) genes, is common in Appaloosa horses (Sandmeyer et al. 2007), although it has been reported in American Quarter Horse (Gelatt, 1993), Thoroughbred, Paso Fino (Nunnery et al., 2005), and Standardbred (Rebhun, 1992). However, this disease has not yet been described in the Mangalarga Marchador breed. Homozygosis for the gene complex, in addition to the loss of functionality of the photoreceptor rods (due to the absence of the TRPM1 channels), also leads to typical characteristics such as skin depigmentation and white spots on the coat (Sponenberg \& Bellone, 2017). Coat depigmentation is not only noted in Appaloosa horses but also in gray-coated animals (Bellone et al., 2013), along with the fillies under study. Presence of striped hooves and depigmented bulbar conjunctiva are other phenotypic characteristics commonly observed in CSNB (Bellone et al., 2013), which were evident in case 2, although case 1 did not present with the same.

CSNB diagnosis using electroretinography suggested the absence of wave "b" corresponding to the activation of bipolar cells associated with rods (ERG negative) (Witzel et al., 1977). However, this electroretinographic pattern does not seem to be a characteristic feature of the disease because it has been observed in other types of rod dysfunctions that were not associated with 
the Leopard Complex, as demonstrated in this study. A recent study highlighted another different mutation in the TRPM1 channel of bipolar cells associated with the photoreceptor rods that were not associated with the Leopard Complex (Scott et al., 2016). This mutation appeared to promote a substitution of a nitrogen base in the coding gene for the channel, resulting in non-functional mRNA transcripts, which interrupted its maturation (Scott et al., 2016). However, this pathology was not tested for the fillies under study, and further research will be required to rule out this mutation.

Another form of ophthalmic disease associated with skin depigmentation is the multiple congenital ocular abnormality (MCOA), which includes several abnormalities associated with homozygosis for animals with a gray coat (Ramsey et al., 1999a; Ewart et al., 2000), such as multiple cysts in the iris, cornea globosa, iris hypoplasia, dyscoria, and retinal and pectinate ligament dysplasia. This disease was previously called anterior segment dysplasia (Ramsey et al., 1999a, 1999b; Ewart et al., 2000; Grahn et al., 2008). In the reported cases, the animals do not present any of the signs described in MCOA. However, whether the retinal dysfunction associated with the photoreceptor rods is a component of MCOA remains unknown. Therefore, additional and more in-depth studies involving genomics, vision electrophysiology, and retinal histopathology of the horses need to be conducted in affected animals.

In addition to visual impairment in a scotopic environment, both cases presented here also demonstrated low visual capacity in a photopic environment, confirmed by the ERG. The ERG waves "a" and "b" did not present with normal amplitudes or ITs for both the scotopic and photopic phases of the protocol, indicating a severe impairment in the photoreceptor rods and less severe impairment of the cones or the accessory bipolar cells. Moreover, a genealogical survey of the animals presented in this report suggested that they were closely related, in which the father of the filly in case 1 was the maternal grandfather of the filly in case 2 . Therefore, it is possible that the disease observed in the animals has a genetic nature. However, genealogical studies with a larger number of documented cases should be conducted for this characterization. Additionally, animals should be monitored to assess whether their night blindness evolves into complete blindness or does not progress as is the case with CSNB.

\section{Conclusion}

Based on the examinations performed, along with the clinical history and the genealogical research of the animals, it is considerably possible that both animals have congenital night blindness. However, this disease is not associated with the Leopard Complex, confirmed by the genetic examination performed. Moreover, the animals also presented with some visual impairment in bright environments, highlighted by the decrease in the electrical activity of cones.

Therefore, new research is needed to characterize the night blindness in Mangalarga Marchador horses.

\section{References}

Bellone, R. R. (2017). Genetic testing as a tool to identify horses with or at risk for ocular disorders. Veterinary Clinics: Equine Practice, 33(3), 627-645. http://dx.doi.org/10.1016/j.cveq.2017.08.005. PMid:29103563.

Bellone, R. R., Holl, H., Setaluri, V., Devi, S., Maddodi, N., Archer, S., Sandmeyer, L., Ludwig, A., Foerster, D., Pruvost, M., Reissmann, M., Bortfeldt, R., Adelson, D. L., Lim, S. L., Nelson, J., Haase, B., Engensteiner, M., Leeb, T., Forsyth, G., Mienaltowski, M. J., Mahadevan, P., Hofreiter, M., Paijmans, J. L., Gonzalez-Fortes, G., Grahn, B., \& Brooks, S. A. (2013). Evidence for a retroviral insertion in TRPM1 as the cause of congenital stationary night blindness and leopard complex spotting in the horse. PLoS One, 8(10), e78280. http://dx.doi.org/10.1371/ journal.pone.0078280. PMid:24167615.

Crispin, S. M. (2000). Developmental anomalies and abnormalities of the equine iris (3rd ed., pp. 93-98). Philadelphia: Veterinary Ophthalmology. http://dx.doi.org/10.1046/j.1463-5224.2000.00113.x.

Ekesten, B., Komáromy, A. M., Ofri, R., Petersen-Jones, S. M., \& Narfström, K. (2013). Guidelines for clinical electroretinography in the dog: 2012 update. Documenta Ophthalmologica, 127(2), 79-87.

Ewart, S. L., Ramsey, D. T., Xu, J., \& Meyers, D. (2000). The horse homolog of congenital aniridia conforms to codominant inheritance. The Journal of Heredity, 91(2), 93-98. http://dx.doi.org/10.1093/jhered/91.2.93. PMid:10768120.

Gelatt, K. N. (1993). Congenital and acquired ophthalmic diseases in the foal. Animal Eye Research, 1(2), 15-27. 
Grahn, B. H., Pinard, C., Archer, S., Bellone, R., Forsyth, G., \& Sandmeyer, L. S. (2008). Congenital ocular anomalies in purebred and crossbred Rocky and Kentucky Mountain horses in Canada. The Canadian Veterinary Journal. La Revue Veterinaire Canadienne, 49(7), 675-681. PMid:18827844.

Maggs, D. J., \& Miller, P., \& Ofri, R. (2012). Slatter's fundamentals of veterinary ophthalmology (pp. 299). USA: Elsevier Health Sciences.

Nunnery, C., Pickett, J. P., \& Zimmerman, K. L. (2005). Congenital stationary night blindness in a Thoroughbred and a Paso Fino. Veterinary Ophthalmology, 8(6), 415-419. http://dx.doi.org/10.1111/j.1463-5224.2005.00416.x. PMid:16359365.

Pickett, J. P., Lindley, D. M., Boosinger, T. R., \& Toivio-Kinnucan, M. (1991). Stationary night blindness in a collie. Progress in Veterinary and Comparative Ophthalmology, 1, 303-308.

Ramsey, D. T., Ewart, S. L., Render, J. A., Cook, C. S., \& Latimer, C. A. (1999a). Congenital ocular abnormalities of Rocky Mountain Horses. Veterinary Ophthalmology, 2(1), 47-59. http://dx.doi.org/10.1046/j.1463-5224.1999.00050.x. PMid:11397242.

Ramsey, D. T., Hauptman, J. G., \& Petersen-Jones, S. M. (1999b). Corneal thickness, intraocular pressure, and optical corneal diameter in Rocky Mountain Horses with cornea globosa or clinically normal corneas. American Journal of Veterinary Research, 60(10), 1317-1321. PMid:10791948.

Rebhun, W. C. (1992). Retinal and optic nerve diseases. The Veterinary Clinics of North America. Equine Practice, 8(3), 587-608. http://dx.doi.org/10.1016/S0749-0739(17)30443-1. PMid:1458331.

Rosa, M., Botteon, P. D., Pereira, J. S., Brooks, D. E., \& Rosa, M. V. (2014). Evaluation of equine electroretinographic responses by using two different electrodes and four different Alpha-2 agonist sedatives. Revista Brasileira de Medicina Veterinária, 36(4), 367-374.

Sandmeyer, L. S., Breaux, C. B., Archer, S., \& Grahn, B. H. (2007). Clinical and electroretinographic characteristics of congenital stationary night blindness in the Appaloosa and the association with the leopard complex. Veterinary Ophthalmology,10(6), 368-375. http://dx.doi.org/10.1111/j.1463-5224.2007.00572.x. PMid:17970998.

Schubert, G., \& Bornschein, H. (1952). Contribution to the analysis of the human electroretinogram. Ophthalmologica, 123(6), 396-413. http://dx.doi.org/10.1159/000301211. PMid:14957416.

Scott, M. L., John, E. E., Bellone, R. R., Ching, J. C. H., Loewen, M. E., Sandmeyer, L. S., Grahn, B. H., \& Forsyth, G. W.. (2016). Redundant contribution of a transient receptor potential cation channel member 1 exon 11 single nucleotide polymorphism to equine congenital stationary night blindness. BMC Veterinary Research, 12(1), 121. http://dx.doi.org/10.1186/s12917-016-0745-1. PMid:27329127.

Sponenberg, D. P., \& Bellone, R. (2017). Equine color genetics (4th ed.). UK: John Wiley \& Sons.

Witzel, D. A., Joyce, J. R., \& Smith, E. L. (1977). Electroretinography of congenital night blindness in an Appaloosa filly. Journal of Equine Medicine and Surgery, 1, 226-229.

Yanoff, M., Duker, J. S., \& Bakri, S. (2016). Yanoff \& duker retina and vitreous. USA: Elsevier. 